\title{
Phylogenetic analysis of two Ukrainian isolates of Wheat streak mosaic virus
}

\author{
L. T. Mishchenko', A. A. Dunich ${ }^{1}$, I. Ya. Skrypkina ${ }^{2}$, N. O. Kozub ${ }^{3}$ \\ ${ }^{1}$ ESC "Institute of Biology and Medicine", Taras Shevchenko National University of Kyiv \\ 64/13, Volodymyrska Str., Kyiv, Ukraine, 01601 \\ ${ }^{2}$ Institute of Molecular Biology and Genetics, NAS of Ukraine \\ 150, Akademika Zabolotnoho Str., Kyiv, Ukraine, 03143 \\ ${ }^{3}$ Institute of Food Biotechnology and Genomics, NAS of Ukraine \\ 2A, Osipovskogo Str., Kyiv, Ukraine, 04123 \\ lmishchenko@ukr.net,korenevochka1983@ukr.net
}

The study of molecular characteristics and, in particular, the nucleotide (nt) and amino acid (aa) sequences of the viral genomes, is necessary to know the changes in their geographical range, phylogenetic relationships, viruses' evolution, and their emergence as new epidemics.

Aim. Phylogenetic analysis of the coat protein $(C P)$ gene sequences of two new Ukrainian isolates of Wheat streak mosaic virus: Ukraine-Mal-18 and Ukraine-Ep-18. Results. The nucleotide sequences of $676 \mathrm{nt}$ region of the $C P$ gene of two Ukrainian WSMV isolates were compared with the sequences of $72 \mathrm{WSMV}$ isolates/strains from GenBank. The phylogenetic analysis showed that the Ukrainian WSMV isolates cluster with the clade B or WSMV- $\triangle E$ isolates (originating from Europe and Asia) and have a typical for this clade triplet deletion at the position 8412-8414 nt in the $C P$ gene. The isolate Ukraine-Mal-18 has the highest level of the sequence identity (93.5\%-95.9\% nt and 93.6-95.0\% aa) with the clade B isolates. The Ukraine-Ep-18 isolate shares 89.2 \%-91.4 \% (nt) and 88.6-87.1\% (aa) identity with the clade $\mathrm{B}$ isolates. Additionally, both Ukrainian WSMV isolates have a number of unique aa substitutions in the central $C P$ gene domain. Conclusions. Ukrainian WSMV isolates belong to the clade B. But Ukraine-Mal-18 and Ukraine-Ep-18 have some differences from other members of the clade: i) a higher divergence compared to other B isolates (the Ukraine-Mal-18 has 12 aa substitutions, the Ukraine-Ep-18 has 25 aa substitutions, where as the other clade B isolates have no more than 2 aa substitutions); ii) have aa substitution identical with the B1 non-crop isolates of this virus, many aa substitutions are in the same motifs as the substitutions of $\mathrm{B} 1$ grass WSMV isolates.

Ke y w o r d s: Wheat streak mosaic virus, Triticum aestivum, phylogenetic analysis, sequencing, coat protein

(C) 2019 L. T. Mishchenko et al:; Published by the Institute of Molecular Biology and Genetics, NAS of Ukraine on behalf of Biopolymers and Cell. This is an Open Access article distributed under the terms of the Creative Commons Attribution License (http://creativecommons.org/licenses/by/4.0/), which permits unrestricted reuse, distribution, and reproduction in any medium, provided the original work is properly cited 


\section{Introduction}

In recent years, not only the number and prevalence of cereal viruses have increased expressively, but also their economic significance [1, 2]. Wheat streak mosaic virus (WSMV) is the most harmful and widespread virus of cereals in all wheat grown areas in the world. WSMV can cause significant yield losses of wheat - up to $60 \%$ [3] and in some cases - up to $100 \%$. That is why a detail investigation of WSMV is warranted. WSMV is spread and detected in USA, Canada, Argentina, Australia, Asia, and Europe. In Europe, WSMV was found in Romania, Austria, Czech Republic, France, Hungary, Turkey, Italy, Poland, Russia, Slovakia, and Ukraine. In Lithuania and Germany, this virus was first detected only in $2013[4,5]$. The WSMV hosts are plant species of the family Poaceae. The main of them are: wheat, barley, maize, oat and many other grasses [6-8]. These species are reservoirs of the virus and its vector.

The study of molecular characteristics and in particular, the nucleotide sequences of the genome, provides an opportunity to follow the virus phylogenetic relationships with others, to elucidate its evolutionary history and prospects. Furthermore, based on these data it is possible to predict the changes and emergence of new properties in the strains or isolates circulating in a specific area.

Based on the coat protein (CP) gene sequences, WSMV isolates have been divided into four clades, named A-D $[4,9,10]$.

Clade A represents one isolate from Mexico, known as El-Batán. Clade B or WSMV- $\Delta \mathrm{E}$ includes Asian and European isolates [4, 11]. $\mathrm{B}$ isolates have a deletion of triplet codon GCA
(Glycine amino acid) in the $C P$ gene sequence [11]. Except the $C P$ gene, the differences between isolates from different clades were revealed in the putative protein $\mathrm{P} 1 /$ helper-component-proteinase (HC-Pro) protease cleavage site $[4,12]$.

Recently, Singh \& Kundu [8] proposed a new clade B1 for the WSMV isolates infecting grasses. This clade includes Czech isolates: ar1 detected in Agropyron repens (KY419572), pp1 from Phleum pratense (KY419573), and pp2 from Poa pratensis (KY419574). It was shown that these grass WSMV isolates are more similar to the $\mathrm{B}$ isolates rather than to $\mathrm{A}$ and $\mathrm{D}$ isolates. Moreover, the Czech grass isolates are characterized by the presence of a triplet deletion at the position 8412-8414 nt in the $C P$ gene as well as the clade $\mathrm{B}$ isolates. On the other hand, the B1 isolates were slightly different from previously described the WSMV isolates from Czech Republic and had several aa substitutions located in the central domain of the $C P$ gene [8].

Clade $\mathrm{C}$ comprises isolate from Iran (Ac. No AF454458) [13].

Clade D includes isolates from USA, Canada, Argentina, Australia, Canada, Turkey (AF454455), and Iran (EU914917) [13, 14]. Interestingly, some USA WSMVs have Gly deletion in the $C P$ gene as well as $\mathrm{B}$ isolates [14]. The clade $D$ isolates are divided into four subclades, D1-D4 $[15,16]$. This clade also includes WSMV described as isolate Ger (Ac. No AJ889242). Isolate Ger actually represents the strain PV57 from North America which had been maintained in the virus collection of the former Institute for Resistance Research and Pathogen Diagnostics in Aschersleben, Germany [4]. 
Analysis of the WSMV whole genomes showed that the clustering of some of them into different clades is based not only on geographical origin. Isolate Saadat-Shahr (Ac. No EU914918) is in the clade B, isolate with Ac. No AF454458 is in the clade C, and one more Iranian isolate Naghadeh (Ac. No EU914917) has high genetic similarity with the clade D isolates [4]. Similar situation is with Turkish isolates. Whereas the isolate Turkei (Ac. No FJ606886) clustered with European isolates from the clade $\mathrm{B}$, another Turkish isolates Turkey1 (Ac. No AF454455) and Turkey2 (Ac. No AF454457) clustered with isolates from the clade D [17]. Isolate Agdia (FJ695510) from Czech Republic is also grouped with the clade $\mathrm{D}$ isolates.

Noteworthy, considerable attention is paid to the study of wheat viruses in Ukraine, in particular, WMSV. The WSMV investigation was started in 1968 [18]. In the 1990s the disease was marked with different intensity on winter wheat crops in many regions [19]. Further, study on the WSMV circulation in Ukraine has shown that the virus is distributed in the central and eastern regions of the country. Later, an increase in the impact of climate change on the manifestation and circulation of this virus has been marked [3,20]. Monitoring of wheat crops in the Poltava, Kyiv and Kharkiv regions of Ukraine in the last years has shown minor damage with WSMV. Earlier, some molecular properties of Poltava isolate of WSMV were investigated [3]. In 2018, we noted the streak symptoms in the fields of winter wheat in the Kharkiv region. So, this study describes the phylogenetic analysis of the $C P$ gene sequences of two new Ukrainian isolates of Wheat streak mosaic virus.

\section{Materials and Methods}

Samples collection. Winter wheat leaf samples with streak symptoms were collected in May 2018 in the fields of Kharkiv region (east part of Ukraine).

Enzyme-linked immunosorbent assay. Identification of the viruses in sap of wheat leaves was performed by double-antibody sandwich enzyme-linked immunosorbent assay (DAS-ELISA). Specific antibodies against Wheat streak mosaic virus (WSMV) and Barley yellow mosaic virus (BYDV-PAV) (Loewe, Germany) were used. Antigen samples were prepared by grinding leaf tissue in PBS buffer, $\mathrm{pH} 7.4$, at the ratio 1:2 (w/V). Leaf samples from healthy wheat were also included as negative controls. Positive controls were commercial (Loewe, Germany). The results were recorded on Termo Labsystems Opsis MR reader (USA) with Dynex Revelation Quicklink software at the wavelength of 405 $\mathrm{nm}$. Samples were considered positive when their absorbance values at $405 \mathrm{~nm}$ were at least three times higher than those of negative controls [21].

$R N A$ extraction, RT-PCR and sequencing. Total RNA was extracted from fresh leaves using RNeasy Plant Mini kit (Qiagen, Great Britain) following the manufacturer's instructions. Two-step RT-PCR was performed. The reverse transcription was performed using RevertAid Reverse Transcriptase (Thermo Scientific, USA) according to the manufacturer's instructions. Amplification was performed using thermocycler (Genetic research instrumentation LTD, Great Britain). WSMV CP-specific primers were used: WS-8166F $5^{\prime}$ GAGAGCAATACTGCGTGTACG 3' and WS8909R 5' GCATAATGGCTCGAAGTGATG 
3' [22]. DNA product of $750 \mathrm{bp}$ was amplified. Amplification was performed in $12.5 \mu \mathrm{l}$ of Dream Taq PCR Master Mix (2x) buffer (containing Dream Taq DNA polymerase, $2 \mathrm{x}$ Dream Taq buffer, $0.4 \mathrm{mmol} / 1$ of each dNTP and $4 \mathrm{mmol} / 1$ of $\mathrm{MgCl}_{2}$ ), $7.5 \mu \mathrm{l}$ of nucleasefree water, $1 \mu \mathrm{l}$ of each primer $(10 \mu \mathrm{mol} / \mathrm{l})$, and $3 \mu \mathrm{l}$ of cDNA. The temperature regime for amplification reactions was as follows: initial denaturation for $3 \mathrm{~min}$ at $95^{\circ} \mathrm{C}$, followed by 35 cycles of $95^{\circ} \mathrm{C}$ for $30 \mathrm{~s}, 55^{\circ} \mathrm{C}$ for $30 \mathrm{~s}$, and $72^{\circ} \mathrm{C}$ for $1 \mathrm{~min}$. The final extension was at $72^{\circ} \mathrm{C}$ for $10 \mathrm{~min}$. PCR products were separated on a $1.5 \%$ agarose gel with DNA markers MassRuler DNA Ladder Mix ready-to-use (SM 0311, Thermo Scientific, USA), stained with ethidium bromide, and visualized under UV light. The PCR products were purified from the agarose gel using a QIAquick Gel Extraction Kit (Qiagen, Great Britain). Sequencing of the purified amplified DNA fragments was carried out with the 3130 Genetic Analyzer (Applied Biosystems, USA).

Phylogenetic analysis. Sequences of Ukrainian WSMV isolates were compared with WSMV sequences in the NCBI database with the BLAST program (http:// www.ncbi.nlm. him.gov). WSMV isolates used in this study are listed in Table 1. Nucleotide and amino acid sequences were aligned using Clustal W in MEGA 7 (http://www.megasoftware.net/). Phylogenetic tree for the part of coat protein gene of 2 Ukrainian WSMV isolates and 72 WSMV isolates from different countries was constructed by the Neighbor-Joining method [23] using the best-fitting model (Jukes Cantor). To check the reliability of the constructed tree we used bootstrap test with 1000 bootstrap replications. Multiple alignments of the coat protein amino acid sequences (225 aa) of WSMV isolates were performed by BioEdit program.
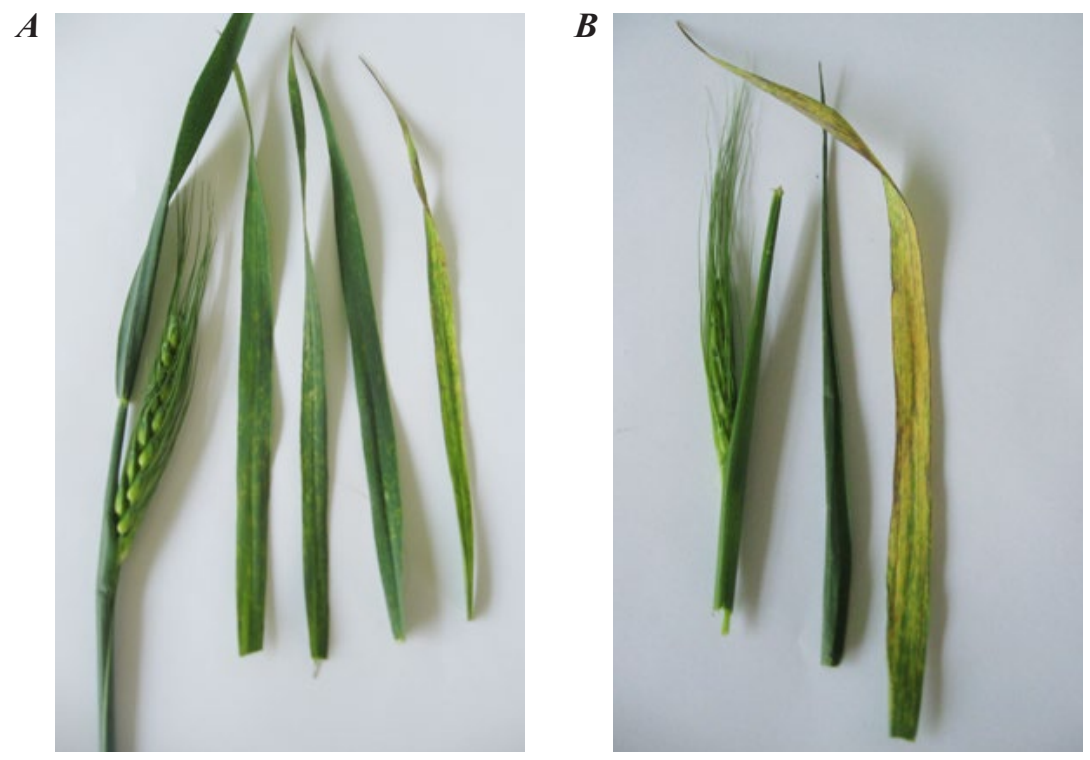

Fig. 1. Winter wheat with symptoms of WSMV-infection: a - cv. Malynivka; b - cv. Epokha Odeska 


\section{Results and Discussion}

In 2018, winter wheat plants cv. Malynivka and Epokha Odeska with WSMV-like mild and severe streak symptoms were found near Kharkiv in the east part of Ukraine (Fig.1).
DAS-ELISA and RT-PCR showed that both wheat samples were infected with WSMV. BYDV-PAV antigens were not detected. These two samples were taken for this study. The WSMV isolate from wheat cv. Malynivka was

Table 1. Nucleotide and amino acid sequence identity of part of the CP gene of the Ukrainian WSMV isolates with isolates/strains from other countries (\%)

\begin{tabular}{|c|c|c|c|c|c|c|c|c|c|}
\hline \multirow{2}{*}{ No. } & \multirow{2}{*}{$\begin{array}{c}\text { Isolate / strain } \\
\text { name }\end{array}$} & \multirow{2}{*}{$\begin{array}{l}\text { Accession No } \\
\text { in GenBank }\end{array}$} & \multirow{2}{*}{ Host } & \multirow{2}{*}{ Country of origin } & \multicolumn{2}{|c|}{ Ukraine-Mal-18 } & \multicolumn{2}{|c|}{ Ukraine-Ep-18 } & \multirow{2}{*}{ Clade } \\
\hline & & & & & nt & aa & nt & aa & \\
\hline 1 & El Batan 3 & AF285170 & wheat & Mexico & 66.0 & 76.7 & 62.6 & 70.3 & A \\
\hline 2 & Ukraine-Mal-18 & MH523356 & wheat & Ukraine & ----- & ----- & 95.7 & 93.6 & B \\
\hline 3 & Ukraine-Ep-18 & MH523357 & wheat & Ukraine & 95.7 & 93.6 & ----- & $\begin{array}{ll}----- \\
\end{array}$ & $\mathrm{B}$ \\
\hline 4 & Russia & AF454459 & wheat & Russia & 95.9 & 95.0 & 91.4 & 88.6 & B \\
\hline 5 & Marmagne & HG810953 & wheat & France & 94.9 & 95.0 & 91.2 & 88.6 & $\mathrm{~B}$ \\
\hline 6 & Czech & AF454454 & wheat & Czech Republic & 94.9 & 95.0 & 90.8 & 88.6 & $\mathrm{~B}$ \\
\hline 7 & Austria & LN624217 & wheat & Austria & 94.2 & 94.1 & 90.3 & 87.6 & B \\
\hline 8 & Hoym & HG810954 & wheat & Germany & 94.7 & 94.6 & 90.6 & 88.1 & $\mathrm{~B}$ \\
\hline 9 & Hungary & AF454456 & wheat & Hungary & 94.4 & 94.6 & 90.3 & 88.1 & $\mathrm{~B}$ \\
\hline 10 & Saadat-Shahr & EU914918 & wheat & Iran & 88.8 & 94.6 & 84.8 & 88.6 & $\mathrm{~B}$ \\
\hline 11 & Toskana & FJ606885 & wheat & Italy & 95.0 & 95.0 & 91.4 & 88.6 & $\mathrm{~B}$ \\
\hline 12 & Burgund & FJ606884 & wheat & France & 94.0 & 95.0 & 90.6 & 88.6 & $\mathrm{~B}$ \\
\hline 13 & WSMV-1313 & KJ720819 & wheat & Lithuania & 94.7 & 94.6 & 90.6 & 88.1 & $\mathrm{~B}$ \\
\hline 14 & SK512 & FJ613359 & wheat & Slovakia & 95.0 & 94.6 & 91.0 & 88.1 & $\mathrm{~B}$ \\
\hline 15 & SK349 & EU723085 & wheat & Slovakia & 95.0 & 95.0 & 90.8 & 88.6 & $\mathrm{~B}$ \\
\hline 16 & SK350 & EU723086 & wheat & Slovakia & 94.7 & 95.0 & 90.6 & 88.6 & $\mathrm{~B}$ \\
\hline 17 & WSMV-Sz & KP261825 & wheat & Poland & 93.5 & 94.1 & 90.1 & 87.6 & $\mathrm{~B}$ \\
\hline 18 & Turkei & FJ606886 & wheat & Turkey & 95.0 & 95.0 & 91.0 & 88.6 & $\mathrm{~B}$ \\
\hline 19 & TR & KC900901 & wheat & Turkey & 93.5 & 94.6 & 89.2 & 88.1 & $\mathrm{~B}$ \\
\hline 20 & KosHJR_ & FJ216409 & wheat & Czech Republic & 95.4 & 95.0 & 91.4 & 88.6 & $\mathrm{~B}$ \\
\hline 21 & Policko-CRI & FJ216412 & wheat & Czech Republic & 95.2 & 95.0 & 91.2 & 88.6 & $\mathrm{~B}$ \\
\hline 22 & Turondot & KY419568 & wheat & Czech Republic & 95.0 & 95.0 & 91.2 & 88.6 & $\mathrm{~B}$ \\
\hline 23 & Hymack & KY419569 & wheat & Czech Republic & 95.0 & 95.0 & 91.2 & 88.6 & $\mathrm{~B}$ \\
\hline 24 & PoleR & FJ216410 & wheat & Czech Republic & 95.0 & 95.0 & 91.0 & 88.6 & $\mathrm{~B}$ \\
\hline 25 & SlastJR & FJ216414 & wheat & Czech Republic & 94.5 & 94.6 & 90.5 & 88.1 & $\mathrm{~B}$ \\
\hline 26 & WSMVcz1 & FJ216408 & wheat & Czech Republic & 94.7 & 94.6 & 90.6 & 88.1 & $\mathrm{~B}$ \\
\hline 27 & Bodycek & KY419571 & wheat & Czech Republic & 94.2 & 94.6 & 90.3 & 88.1 & $\mathrm{~B}$ \\
\hline 28 & Avenue & KY419570 & wheat & Czech Republic & 94.0 & 93.6 & 90.1 & 87.1 & $\mathrm{~B}$ \\
\hline 29 & ar1 & KY419572 & Agropyron repens & Czech Republic & 84.4 & 82.2 & 81.0 & 76.7 & B1 \\
\hline 30 & Strain pp1 & KY419573 & Phleum pratense & Czech Republic & 84.2 & 81.7 & 80.8 & 76.2 & $\mathrm{~B} 1$ \\
\hline 31 & Strain pp2 & KY419574 & Poa pratensis & Czech Republic & 84.2 & 81.7 & 80.8 & 76.2 & B1 \\
\hline 32 & Iran & AF454458 & wheat & Iran & 85.6 & 94.1 & 81.6 & 87.6 & $\mathrm{C}$ \\
\hline 33 & Turkey 1 & AF454455 & wheat & Turkey & 84.8 & 93.1 & 81.0 & 86.6 & $\mathrm{D}$ \\
\hline 34 & Ger & AJ889242 & wheat & Germany & 85.2 & 91.6 & 81.6 & 85.1 & $\mathrm{D}$ \\
\hline
\end{tabular}


Phylogenetic analysis of two Ukrainian isolates of Wheat streak mosaic virus

Continued Table 1

\begin{tabular}{|c|c|c|c|c|c|c|c|c|c|}
\hline \multirow{2}{*}{ No. } & \multirow{2}{*}{$\begin{array}{c}\text { Isolate / strain } \\
\text { name }\end{array}$} & \multirow{2}{*}{$\begin{array}{c}\text { Accession No } \\
\text { in GenBank }\end{array}$} & \multirow{2}{*}{ Host } & \multirow{2}{*}{ Country of origin } & \multicolumn{2}{|c|}{ Ukraine-Mal-18 } & \multicolumn{2}{|c|}{ Ukraine-Ep-18 } & \multirow{2}{*}{ Clade } \\
\hline & & & & & nt & aa & nt & aa & \\
\hline 35 & Agdia & FJ695510 & wheat & Czech Republic & 85.4 & 92.1 & 81.8 & 85.6 & $\mathrm{D}$ \\
\hline 36 & Arg1 & FJ348356 & wheat & Argentina & 85.8 & 93.6 & 82.0 & 87.1 & $\mathrm{D}$ \\
\hline 37 & Arg2 & FJ348359 & wheat & Argentina & 85.8 & 93.6 & 82.0 & 87.1 & $\mathrm{D}$ \\
\hline 38 & Arg3 & FJ348357 & wheat & Argentina & 85.8 & 93.6 & 82.0 & 87.1 & $\mathrm{D}$ \\
\hline 39 & PV91H & AF511639 & wheat & Kansas, USA & 85.0 & 92.6 & 81.2 & 86.1 & $\mathrm{D}$ \\
\hline 40 & MO00 & AF511629 & wheat & Missouri, USA & 85.2 & 93.6 & 81.4 & 87.1 & $\mathrm{D}$ \\
\hline 41 & KM93 & AF511621 & wheat & Kansas, USA & 84.6 & 91.6 & 80.8 & 85.1 & $\mathrm{D}$ \\
\hline 42 & Strain Sidney 81 & AF057533 & wheat & Nebraska, USA & 85.2 & 93.1 & 81.4 & 86.6 & $\mathrm{D}$ \\
\hline 43 & ID96 & AF511618 & wheat & Idaho, USA & 84.8 & 94.1 & 81.0 & 87.6 & $\mathrm{D}$ \\
\hline 44 & MON96 & AF511630 & wheat & Montana, USA & 84.6 & 93.1 & 80.8 & 86.6 & $\mathrm{D}$ \\
\hline 45 & OSU & AF511634 & unknown & unknown & 84.4 & 91.1 & 80.8 & 84.7 & $\mathrm{D}$ \\
\hline 46 & CO87 & AF511602 & wheat & Colorado, USA & 84.6 & 90.6 & 81.0 & 84.2 & $\mathrm{D}$ \\
\hline 47 & GO93 & AF511606 & wheat & Kansas, USA & 84.6 & 90.6 & 81.0 & 84.2 & $\mathrm{D}$ \\
\hline 48 & CK93 & AF511598 & wheat & Kansas, USA & 85.0 & 93.1 & 81.2 & 86.6 & $\mathrm{D}$ \\
\hline 49 & KY0083SV & AF511624 & wheat & Kentucky & 84.4 & 92.1 & 80.6 & 85.6 & $\mathrm{D}$ \\
\hline 50 & H95S & AF511614 & sorghum & Kansas, USA & 85.2 & 93.6 & 81.6 & 87.1 & $\mathrm{D}$ \\
\hline 51 & WA99 & AF511643 & maize & Washington, USA & 85.6 & 93.6 & 81.6 & 87.1 & $\mathrm{D}$ \\
\hline 52 & WO93 & AF511644 & maize & Ohio, USA & 85.2 & 93.1 & 81.4 & 86.6 & $\mathrm{D}$ \\
\hline 53 & PV106JM & AF511638 & maize & Ohio, USA & 84.2 & 92.6 & 81.0 & 86.1 & $\mathrm{D}$ \\
\hline 54 & Type strain & AF285169 & wheat & Kansas, USA & 85.0 & 91.6 & 81.4 & 85.1 & $\mathrm{D}$ \\
\hline 55 & PV106H & AF511637 & maize & Ohio, USA & 84.6 & 90.6 & 81.0 & 84.2 & $\mathrm{D}$ \\
\hline 56 & GY93 & AF511607 & maize & Kansas, USA & 85.0 & 93.1 & 81.2 & 86.6 & $\mathrm{D}$ \\
\hline 57 & H94PM & AF511610 & $\begin{array}{l}\text { Pennisetum } \\
\text { glaucum }\end{array}$ & Kansas, USA & 85.0 & 93.6 & 81.4 & 87.1 & $\mathrm{D}$ \\
\hline 58 & WH94S & AF511611 & sorghum & Kansas, USA & 86.0 & 93.1 & 82.2 & 86.6 & $\mathrm{D}$ \\
\hline 59 & H94USDA & AF511612 & sorghum & Kansas, USA & 85.2 & 93.1 & 81.4 & 86.6 & $\mathrm{D}$ \\
\hline 60 & H95LB & AF511613 & $\begin{array}{l}\text { Hordeum } \\
\text { pusillum }\end{array}$ & Kansas, USA & 84.6 & 93.6 & 80.8 & 87.1 & $\mathrm{D}$ \\
\hline 61 & H95S & AF511614 & sorghum & Kansas, USA & 85.2 & 93.6 & 81.6 & 87.1 & $\mathrm{D}$ \\
\hline 62 & H98_Kansas & AF511615 & Chloris virgata & Kansas, USA & 85.8 & 93.6 & 82.2 & 87.1 & $\mathrm{D}$ \\
\hline 63 & Naghadeh & EU914917 & wheat & Iran & 85.4 & 94.6 & 81.4 & 88.1 & $\mathrm{D}$ \\
\hline 64 & Gibson & DQ888803 & wheat & Australia & 85.4 & 93.6 & 81.6 & 87.1 & $\mathrm{D}$ \\
\hline 65 & Mt. Burdett & DQ888801 & wheat & Australia & 85.2 & 93.6 & 81.4 & 87.1 & $\mathrm{D}$ \\
\hline 66 & Tamworth 1 & AY327866 & wheat & Australia & 85.6 & 94.1 & 81.8 & 87.6 & $\mathrm{D}$ \\
\hline 67 & Bordertown & AY327870 & wheat & Australia & 85.6 & 94.1 & 81.8 & 87.6 & $\mathrm{D}$ \\
\hline 68 & Ginninderra & DQ462279 & wheat & Australia & 85.6 & 94.1 & 81.8 & 87.6 & $\mathrm{D}$ \\
\hline 69 & SP-1 & DQ462278 & wheat & Australia & 85.6 & 94.1 & 81.8 & 87.6 & $\mathrm{D}$ \\
\hline 70 & SP-6 & DQ462277 & wheat & Australia & 85.4 & 93.6 & 81.6 & 87.1 & $\mathrm{D}$ \\
\hline 71 & SP-5 & DQ462276 & wheat & Australia & 85.6 & 94.1 & 81.8 & 87.6 & $\mathrm{D}$ \\
\hline 72 & Kondonin & DQ888805 & wheat & Australia & 85.6 & 94.1 & 81.8 & 87.6 & $\mathrm{D}$ \\
\hline 73 & Galong & DQ888804 & wheat & Australia & 85.4 & 93.6 & 81.8 & 87.6 & $\mathrm{D}$ \\
\hline 74 & Yerritup & DQ888802 & wheat & Australia & 85.4 & 93.6 & 81.8 & 87.6 & $\mathrm{D}$ \\
\hline
\end{tabular}




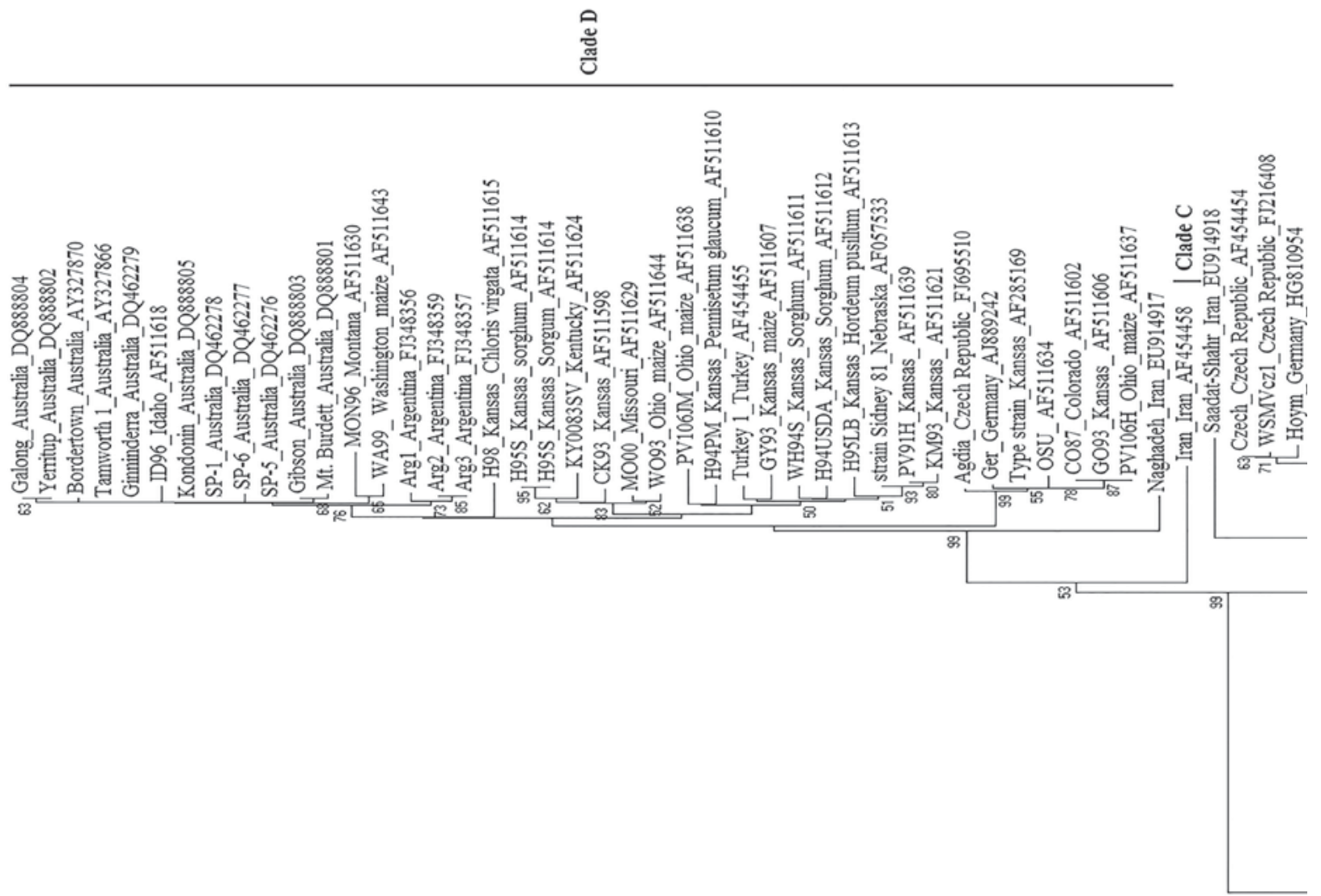



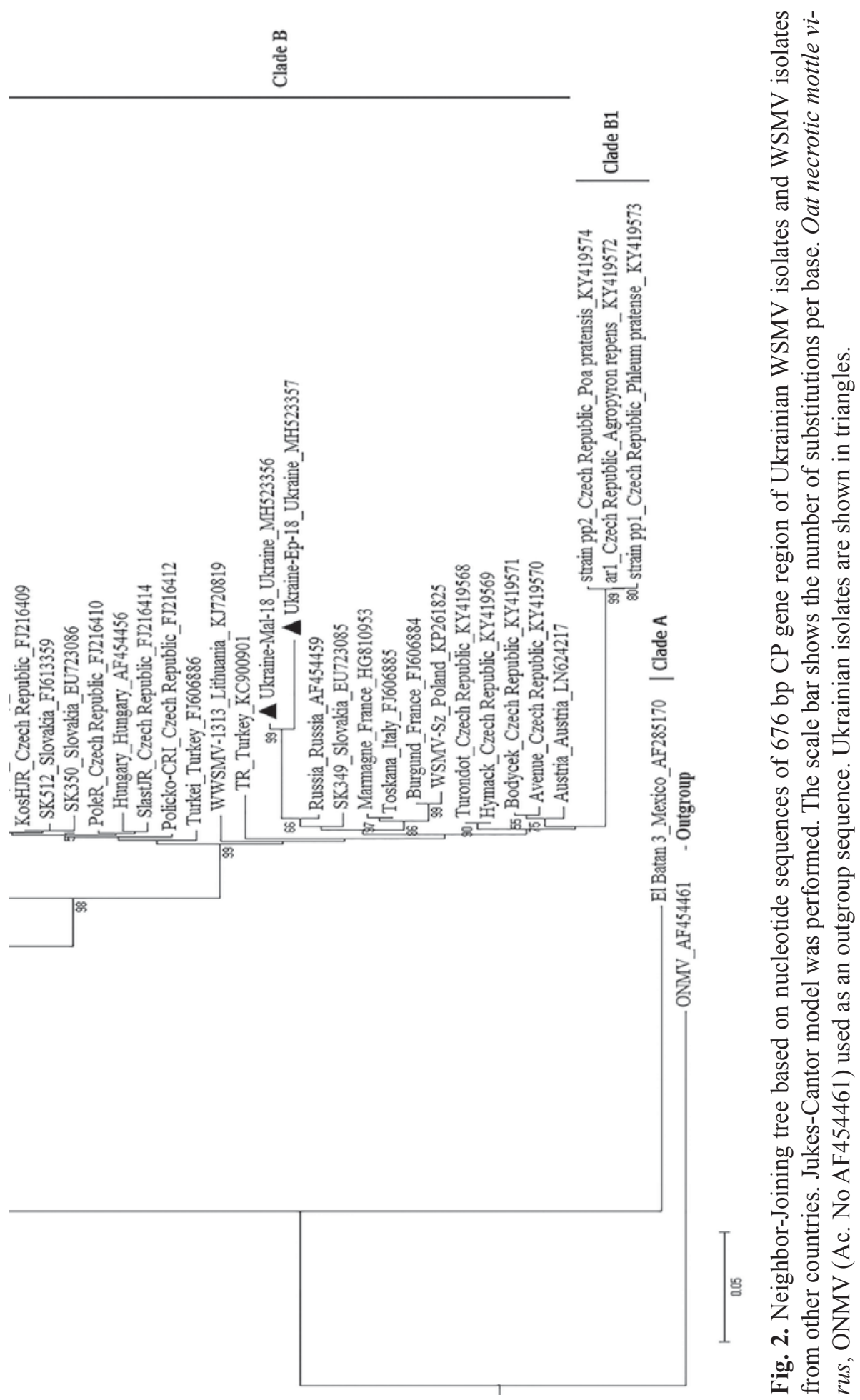


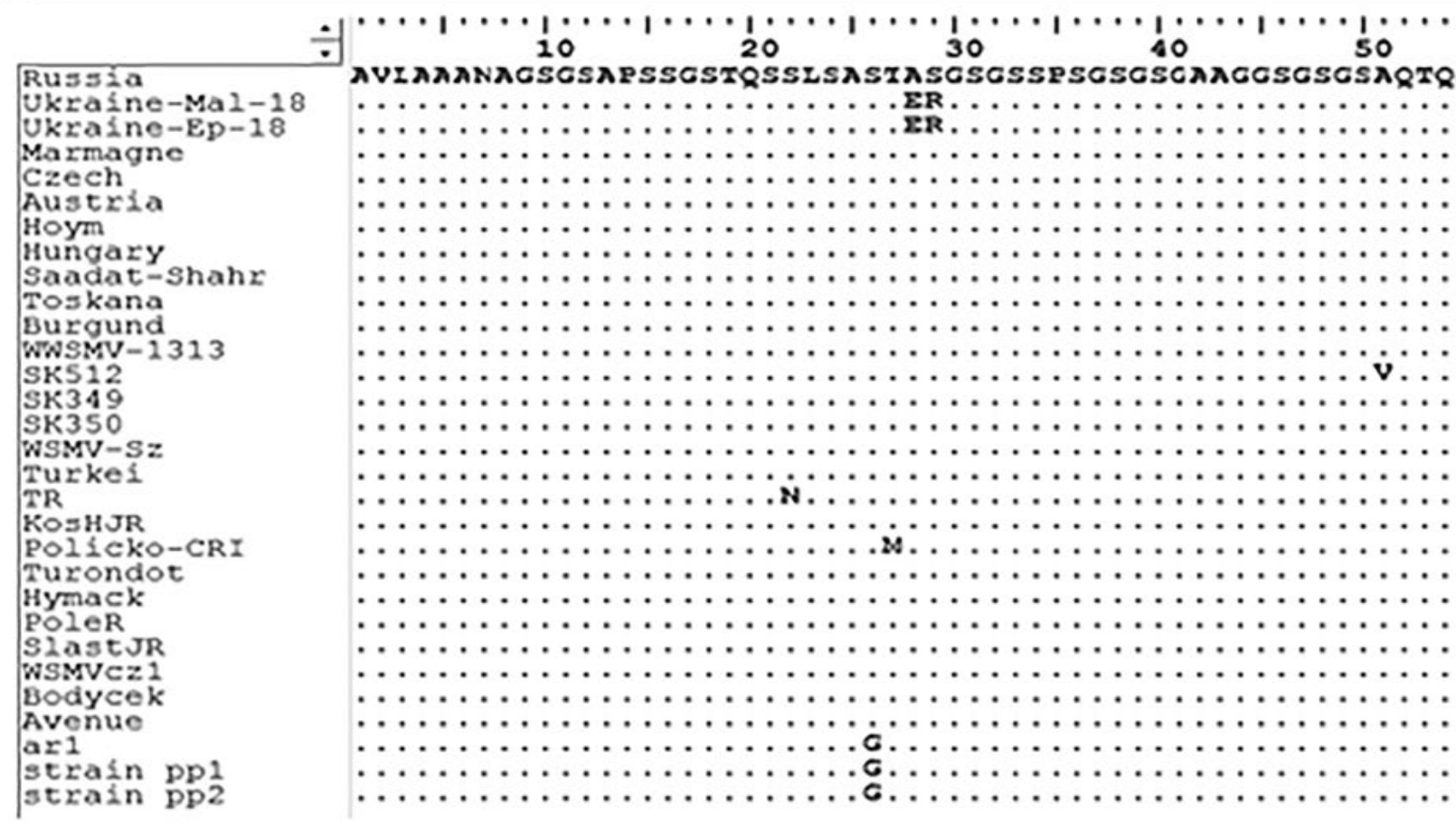

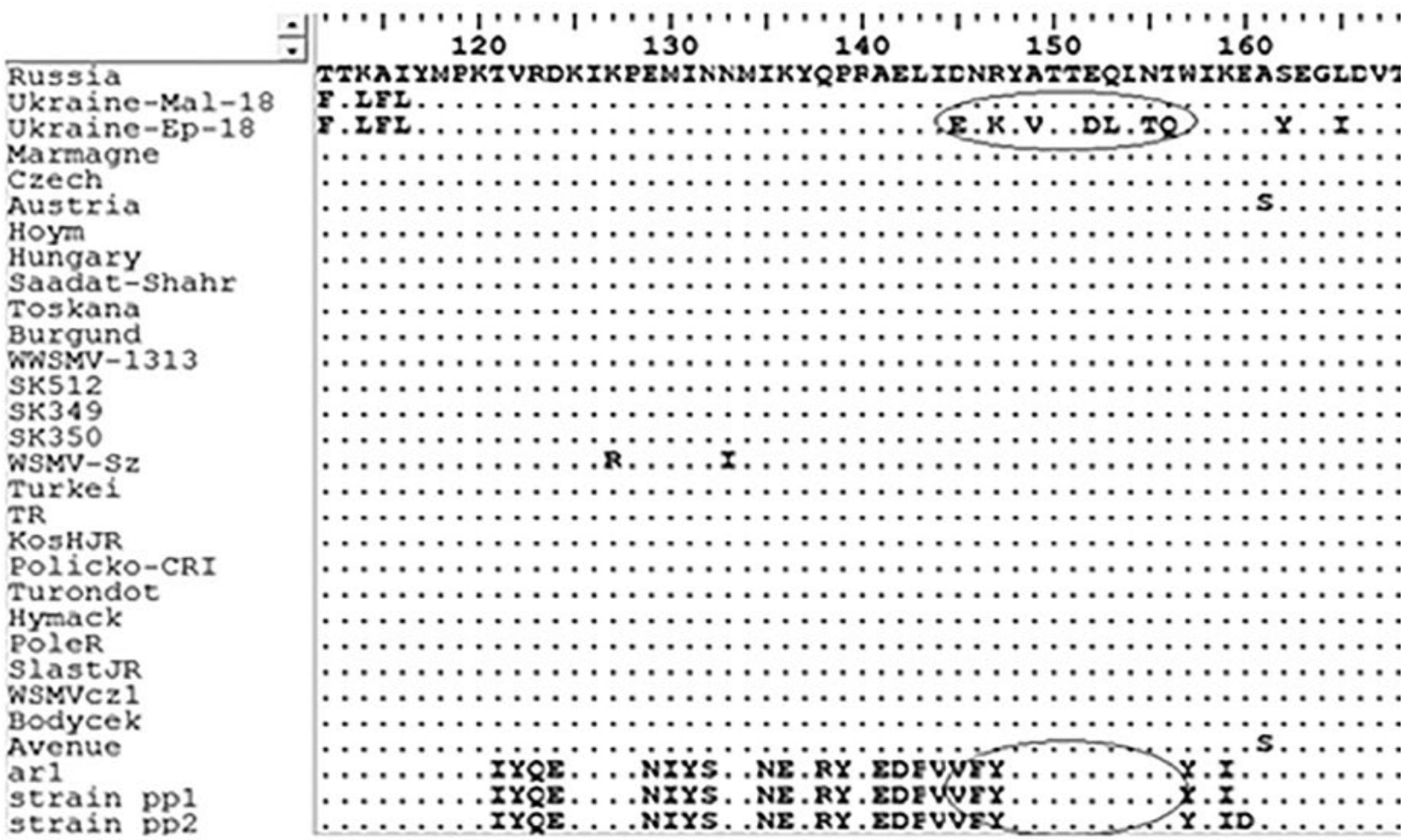




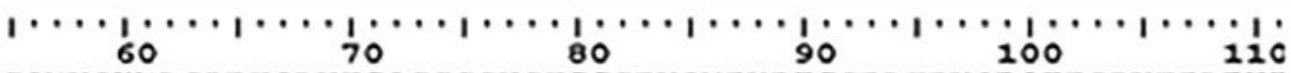
SSNUSUXAGLDTCAKTGQGSGSKGTCGSYUSNEVRTGGRATEVQDRTPGIVFEAPKI

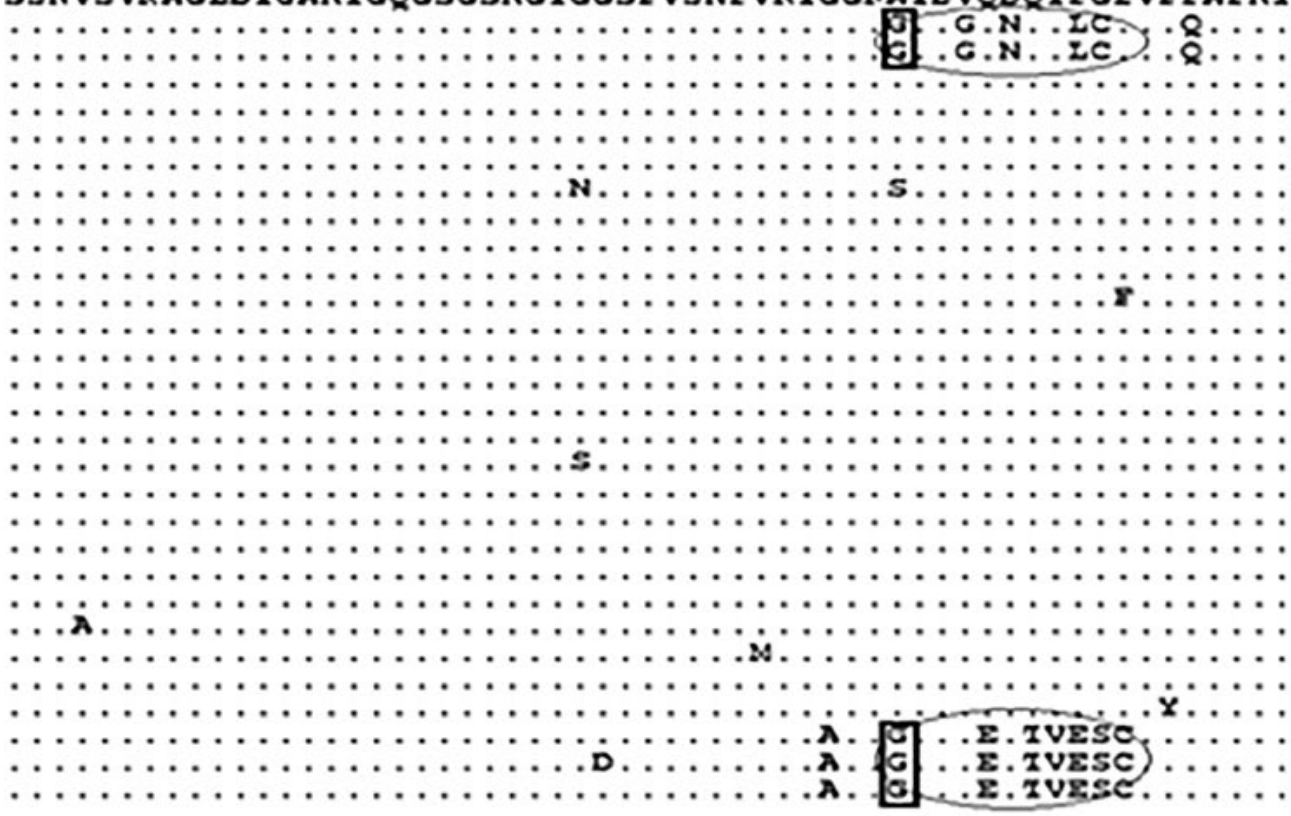

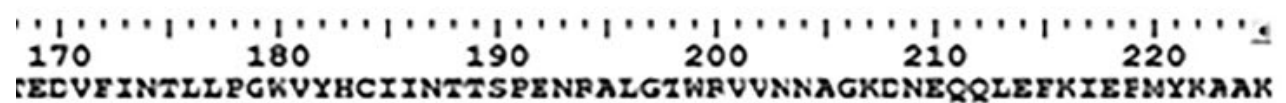

Fig. 3. Comparative analysis of amino acid sequences of Ukrainian WSMV isolates with thevclade B and B1 strains. Identical aa variations among sequences are represented with boxes. Amino acid variations in the same regions are represented with circles. Numbers on top represent the deduced CP amino acid position. Only the differences are shown. Accession numbers for isolates used for the alignment are shown in Table1. 
named Ukraine-Mal-18. The isolate from wheat plants cv. Epokha Odeska was named Ukraine-Ep-18.

Nucleotide (nt) sequences $676 \mathrm{nt}$ region of the $C P$ gene of the Ukrainian WSMV isolates, located at the genomic position 8167-8843, were compared with the sequences of 72WSMV isolates/strains from GenBank. Analysis showed that the Ukrainian WSMV isolates have the highest percentage of identity with all wheat European isolates from the clade B. Isolate Ukraine-Mal-18 has the highest level of the sequence identity (93.5\%-95.9\% nt and 93.6-95.0\% aa) with the clade B isolates. The isolate Ukraine-Ep-18 shares identity of $89.2 \%-91.4 \%$ (nt) and 88.6$87.1 \%$ (aa) with the clade B isolates. (Table 1).

Phylogenetic analysis showed that Ukrainian WSMV isolates with all European and Asian wheat isolates (except isolate Agdia from Czech Republic, Ger from Germany, Turkey 1 from Tukey and Iranian isolate Naghadeh) are clustered into the clade B (Fig. 2).

Ukrainian isolates, like all isolates of the B and $\mathrm{B} 1$ clades, have a triplet deletion at the position 8412-8414 nt in the $C P$ gene in comparison to isolates from the clade D.

Ukraine-Mal-18 and Ukraine-Ep-18 share 80.8 to $82.2 \%$ (nt) and $76.2-82.2 \%$ (aa) identity with isolates from the clade B1, which includes the Czech non-wheat strain ar 1 from Agropyron repens (KY419572), strain pp1 from Phleum pratense (KY419573), and strain pp2 from Poa pratensis (KY419574). Clade $\mathrm{C}$ isolate, represented by Iranian isolate Iran (Ac. No AF454458), showed similarity of $81.6-85.6 \%$ (nt) and 87.6-94.1\% (aa) to the isolates Ukraine-Ep-18 and Ukraine-Mal-18, respectively. Pairwise comparisons of the Ukrainian isolates with sequences of WSMV isolates from the clade $\mathrm{D}$ indicated respective nucleotide and amino acid sequence identities ranging from 80.6 to $85.8 \%$ and 84.2 to $94.6 \%$.

Comparative analysis of aa sequences of Ukrainian isolates with the isolates from clades $\mathrm{B}$ and $\mathrm{B} 1$ revealed significant differences. Thus, the Ukrainian isolate Ukraine-Mal-18 has 12 aa substitutions in the studied region of the $C P$ gene and Ukraine-Ep-18 has 25 aa substitutions, whereas all other isolates of group B have 0 to 2 aa substitutions (Fig. 3).

It is necessary to mention that the substitution $\mathrm{A} \rightarrow \mathrm{G}$ at position aa 94 is identical among the Ukrainian and B1 isolates (Fig. 3). However, all other substitutions revealed in putative $\mathrm{CP}$ amino acid sequences are unique. Additionally, amino acid substitutions were observed at positions aa 112-116 (F.LFL motif in the central region of $C P$ gene). None of WSMV isolates were characterized by such mutations in this region of the $C P$ gene. Noteworthy, many aa substitutions are in the same motifs or near them like substitutions of the $\mathrm{B} 1$ grass WSMV isolates (Fig. 3). These are motifs «№1» (TVESC, 100-104 aa), «№4» (NE.RY.EDPVVFY, 135-147aa) that were previously found in the non-crop WSMV isolates of the B1 clade [8]. Also, the aa sequence of the Ukraine-Ep-18 isolate revealed more aa substitutions in the N-terminal domain of the $\mathrm{CP}$ gene, compared with other WSMV isolates (Fig. 3).

\section{Conclusions}

In our study we revealed that Ukrainian WSMV isolates are clustered into the clade B 
or WSMV- $\Delta \mathrm{E}$. The Ukrainian isolates, like other isolates of the B and B1 clades, have a triplet deletion at the position $8412-8414 \mathrm{nt}$ in the $C P$ gene sequence which led to the absence of Glycine amino acid. Noteworthy, the Ukraine-Ep-18 and Ukraine-Mal-18 isolates are the most divergent among the WSMV- $\Delta \mathrm{E}$ isolates based on amino acid CP sequence. Besides, it was shown that the Ukrainian wheat WSMV isolates have identical aa substitution $(\mathrm{A} \rightarrow \mathrm{G}, 94 \mathrm{aa})$ with the $\mathrm{B} 1$ non-crop isolates of this virus. Also, many aa substitutions are in the same motifs or near them (motif «№1» or TVESC at positions aa 100-104 and motif «№4» or NE.RY.EDPVVFY at positions aa 135-147) that were previously found in the non-crop WSMV isolates of the B1 clade [8]. Also, more aa substitutions in the $C P$ sequence of the Ukraine-Ep-18 isolate were revealed in the N-terminal domain of the $C P$ gene, than all the WSMV isolates taken to our study. It is known that tritimoviruses $\mathrm{N}$-terminal domain of the $C P$ gene is less conserved than the central and C-terminal regions [24]. Also, it was found that major aa variations between the wheat and grasses WSMVs were in the $\mathrm{N}$-terminal region, namely in the motifs 3 and 4 [8]. However, in the wheat isolate UkraineEp-18 we revealed aa substitutions in the motif 4, in comparison to other European wheat WSMVs. Prendeville et al. [25] suggest that mutations in BYDV from wild grass populations can be connected with the virulence factors and can act as positive fitness elements in wild plants. Recently, it has been revealed that the $\mathrm{N}$-terminal region of tritimoviral $\mathrm{CP}$ is involved in the host- and strain-specific longdistance movement [26]. Perhaps, aa substitutions in this $\mathrm{CP}$ region revealed by us for the isolate Ukraine-Ep-18 led to more severe symptoms, compared with the Ukraine-Mal-18 isolate but this requires additional research.

\section{Acknowledgements}

The authors express their gratitude to the colleagues PhD. Nyska I. M and corresponding member of NAASU Petrenkova V.P. from The Plant Production Institute and V. Ya. Yuryev of NAASU for the help in selecting the winter wheat samples.

\section{REFERENCES.}

1. Spaar D, Ordon F, Rabenstein F, Habekuß A, Schliephake E, Schubert J. Economic significance and incidence of cereal viruses in Germany and possibilities to avoid virus caused yield losses. Vestnik zascity rastenij. 2008; 1: 14-26.

2. Byamukama E, Wegulo S, Yabwalo D, Langham MAC. Impact of Wheat streak mosaic virus on wheat production in the northern Great Plains region of the United States: A review. In: Proceedings of the 13th International Plant Virus Epidemiology Symposium, 6-10 June 2016. Avignon, France:72.

3. Mishchenko LT. Viral diseases of winter wheat. Kyiv: Phytosociocenter, 2009. 352 p.

4. Schubert J, Ziegler A, Rabenstein F. First detection of wheat streak mosaic virus in Germany: molecular and biological characteristics. Arch Virol. 2015;160(7):1761-6.

5. Urbanavičiene $L$, Šneideris $D$, Žižytė $M$. Wheat streak mosaic virus detected in winter wheat in Lithuania. Zemdirbyste-Agriculture. 2015; 102(1): 111-4.

6. Chalupníková J, Kundu JK, Singh K, Bartaková P, Beoni $E$. Wheat streak mosaic virus: incidence in field crops, potential reservoir within grass species and uptake in winter wheat cultivars. $J$ Integrat Agricult. 2017; 16(3): 60345-57.

7. DrábT, Svobodová E, Ripl J, Jarošová J, Rabenstein F, Melcher U, Kundu JK. SYBR Green I based RT-qPCR assays for the detection of RNA viruses 
of cereals and grasses. Crop Pasture Sci. 2014; 65(12): 1323-8.

8. Singh $K$, Kundu $J K$. Variations in Wheat streak mosaic virus coat protein sequence among crop and non-crop hosts. Crop Pasture Sci. 2017; 68(4): 328-336.

9. Stenger DC, Seifers DL, French R. Patterns of polymorphism in wheat streak mosaic virus: sequence space explored by a clade of closely related viral genotypes rivals that between the most divergent strains. Virology. 2002;302(1):58-70.

10. Stenger DC, French $R$. Wheat streak mosaic virus genotypes introduced to Argentina are closely related to isolates from the American Pacific Northwest and Australia. Arch Virol. 2009;154(2):331-6.

11. Gadiou S, Kúdela O, Ripl J, Rabenstein F, Kun$d u J K$, Glasa M. An amino acid deletion in Wheat streak mosaic virus capsid protein distinguishes a homogeneous group of European isolates and facilitates their specific detection. Plant Disease. 2009; 93(11): 1209-13.

12. Choi IR, Horken KM, Stenger DC, French R. Mapping of the $\mathrm{P} 1$ proteinase cleavage site in the polyprotein of Wheat streak mosaic virus (genus Tritimovirus). J Gen Virol. 2002;83(Pt 2):443-50.

13. Dwyer GI, Gibbs MJ, Gibbs AJ, Jones RAC. Wheat streak mosaic virus in Australia: relationship to isolates from the Pacific Northwest of the USA and its dispersion via seed transmission. Plant Disease. 2007; 91(2): 164-70.

14. Robinson MD, Murray TD. Genetic variation of wheat streak mosaic virus in the United States Pacific Northwest. Phytopathology. 2013;103(1):98104.

15. *French R, Stenger DC. Wheat streak mosaic virus. CMI/AAB Descriptions of Plant Viruses. 393, Wellesbourne, UK: Assoc. Appl. Biol., 2002.

16. Singh K, Wegulo SN, Skoracka A, Kundu JK. Wheat streak mosaic virus: a century old virus with rising importance worldwide. Mol Plant Pathol. 2018;19(9):2193-2206.

17. Rabenstein F, Seifers DL, Schubert J, French R, Stenger DC. Phylogenetic relationships, strain diversity and biogeography of tritimoviruses. J Gen Virol. 2002;83(Pt 4):895-906.
18. *Oliynyk AN. Wheat streak mosaic in Ukraine. Kyiv, Ukraine, Danylo Zabolotny Institute of Microbiology and Virology, PhD Thesis, 1968.

19. *Reshetnyk GV, Mishchenko LT, Boyko AL, Kolesnyk $L V$. [Detection of Wheat streak mosaic virus in some regions of Ukraine]. Mikrobiol Zh. 1996; 58(2): 39-45.

20. *Mishchenko LT, Dunich AA, Mishchenko IA, Petrenkova VP, Mukha TI. Monitoring of economically important wheat viruses under weather conditions change in Ukraine and investigation of seed transmission of Wheat streak mosaic virus. Bulg $J$ Agricult Sci. 2018; 24(4): 660-9.

21. *Crowther JR. ELISA. Theory and Practice. NY, USA, Hamana Press, 1995. 223 p.

22. Kúdela $O$, Kúdelová $M$, Nováková S, Glasa M. First report of Wheat streak mosaic virus in Slovakia. Disease Notes. 2008; 92(9): 1365.

23. Saitou N, Nei M. The neighbor-joining method: A new method for reconstructing phylogenetic trees. Mol Biol Evol. 1987; 4(4): 406-25.

24. Tatineni $S$, French $R$. The C-terminus of Wheat streak mosaic virus coat protein is involved in differential infection of wheat and maize through hostspecific long-distance transport. Mol Plant Microbe Interact. 2014;27(2):150-62.

25. Prendeville HR, Tenhumberg B, Pilson D. Effects of virus on plant fecundity and population dynamics. New Phytol. 2014;202(4):1346-56.

26. Tatineni S, Van Winkle DH, French $R$. The N-terminal region of wheat streak mosaic virus coat protein is a host- and strain-specific long-distance transport factor. J Virol. 2011;85(4):1718-31.

\section{Філогенетичний аналіз двох українських ізолятів вірусу смугастої мозаїки пшениці}

Л. Т. Міщенко, А. А. Дуніч, І. Я. Скрипкіна, Н. О. Козуб

Дослідження молекулярних характеристик, зокрема, нуклеотидних (нт) та амінокислотних (аa) послідовностей вірусних геномів, $є$ необхідним для з'ясування змін у географічному ареалі, філогенетичних зв'язків, еволюції вірусів та їх появи у вигляді епідемій. Мета. Філогенетичний аналіз гену капсидного білка (CР) 
двох нових українських ізолятів вірусу смугастої мозаїки пшениці (ВСМП) Ukraine-Mal-18 та UkraineЕр-18. Методи: імуноферментий аналіз, виділення тотальної РНК із рослинного матеріалу, полімеразна ланцюгова реакція зі зворотною транскрипцією, сиквенування, філогенетичний аналіз. Результати. Послідовності гену СР розміром 676 нт двох українських ізолятів ВСМП порівнювали із послідовностями 72 ВСМП ізолятів/штамів із бази даних GenBank. Філогенетичний аналіз показав, що українські ізоляти входять до клади В або $W S M V$ - $\triangle E$ (походять із Європи та Азії) та мають типову для цієї клади делецію триплету у позиціях 8412-8414 нт у гені CP. UkraineMal-18 має найвищий відсоток ідентичності за нуклеотидною послідовністю 93,5 \%-95,9 \%, за амінокислотною - 93,6-95,0 \% із ізолятами клади В. Ізолят Ukraine-Ep-18 із ізолятами клади В має ідентичність $89,2-91,4 \%$ (нт) та 88,6 \%- 87,1 \% (аа). Крім того, у двох українських ізолятів відмічено низку унікальних аа заміщень в центральній ділянці гену СР. Висновки. Українські ВСМП ізоляти входять до клади В. Але Ukraine-Mal-18 та Ukraine-Ep-18 мають деякі відмінності від них: i) вищу дивергенцію, ніж інші ізоляти групи В (Ukraine-Mal-18 має 12 аа заміщень, UkraineЕр-18 має 25 аа заміщень, а інші ізоляти клади В мають 0-2 аа заміщення); ii) мають аа заміщення, ідентичні iз непшеничними ізолятами групи В1 цього вірусу, багато аа заміщень знаходяться в тих самих ділянках гену СР, що і заміщення трав'яних В1 ізолятів ВСМП.

К л ю ч о в і с л о в а: вірус смугастої мозаїки пшениці, Triticum aestivum, філогенетичний аналіз, сиквенування, капсидний білок.

\section{Филогенетический анализ двух украинских изолятов вируса полосатой мозаики пшеницы}

Л. Т. Мищенко, А. А. Дунич, И. Я. Скрипкина, Н. А. Козуб

Исследование молекулярных характеристик, в частности, нуклеотидных (нт) и аминокислотных (аa) после- довательностей вирусных геномов, необходимо для выяснения изменений географического ареала, филогенетических связей, эволюции вирусов и их появления в виде эпидемий. Цель. Филогенетический анализ гена капсидного белка (СР) двух новых украинских изолятов вируса полосатой мозаики пшеницы (ВПМП) Ukraine-Mal-18 и Ukraine-Ep-18. Методы. Иммуноферментный анализ, выделение тотальной РНК из растительного материала, полимеразная цепная реакция с обратной транскрипцией, сиквенирование, филогенетический анализ. Результаты. Последовательности гена СР размером 676 нт двух украинских изолятов ВПМП сравнивали с последовательностями 72 ВПМП изолятов / штаммов из базы данных GenBank. Филогенетический анализ показал, что украинские изоляты входят в кладу В или WSMV- $\Delta \mathrm{E}$ (происходят из Европы и Азии) и имеют типичную для этой клады делецию триплета в позициях 8412-8414 нт в гене CP. Ukraine-Mal-18 имеет наиболее высокий процент идентичности по нуклеотидной последовательности 93,5 \%-95,9 \% и аминокислотной - 93,695,0 \% с изолятами клады В. Изолят Ukraine-Ep-18 с изолятами клады В имеет идентичность 89,2-91,4 \% (нт) и 88,6 \% - 87,1 \% (аa). Кроме того, у двух украинских изолятов отмечен ряд уникальных аа замен в центральном участке гена СР. Выводы. Украинские ВПМП изоляты входят в кладу В. Ho Ukraine-Mal-18 и Ukraine-Ep-18 имеют некоторые отличия от них: i) выше дивергенцию, чем другие изоляты В группы (Ukraine-Mal-18 имеет 12 аа замен, Ukraine-Ep-18 имеет 25 аа замен, а другие изоляты клады В имеют от 0 до 2 аа замен); ii) имеют аа замены, идентичны непшеничным изолятам группы В1 этого вируса, много аа замен расположены в тех же участках гена СР, что и замены травяных В1 изолятов ВПМП.

К л ю ч е в ы е с л о в а: вирус полосатой мозаики пшеницы, Triticum aestivum, филогенетический анализ, сиквенирование, капсидный белок.

Received 03.04.2018 